\title{
Research Paper Application of principal component regression analysis in agricultural studies
}

\author{
- P. Sai Shankar, J.V. Narasimham and G. Ananthan
}

See end of the paper for authors' affiliations

Correspondence to :

P. Sai Shankar

Reliance Technology

Group, Hyderabad

(Telangana) India

Email : sai.pothakani

@ ril.com

Paper History :

Received : 09.10.2018;

Revised : 25.01.2019;

Accepted : 06.02.2019
ABSTRACT : This paper presents a combined principal component analysis-regression analysis (PCA-RA) model to study the effects of independent variables namely exposed branches (E.B), yield bearing branches (YBB), total inflorescence (TIFL), average fruits per cluster (AFC) and average females per cluster (AFEC) on total fruit count (TFC). In this section, a multiple linear regression is applied to develop a forecasting model for total fruit count (TFC). Multicollinearity often causes a huge explanatory problem in multiple linear regression analysis. In presence of multi-collinearity the ordinary least squares (OLS) estimators are inaccurately estimated and the co-efficient of independent variables appearing to have the wrong sign. In this paper, the multi-collinearity was detected by using observing correlation matrix and variance influence factor (VIF). This study revealed that principal component regression (PCR) method facilitates to solve the multi-collinearity problem.

KEY WORDS : Multiple regression, Multi-collinearity, Ridge regression, Principal component regression

How To Cite This PAper : Shankar, P. Sai, Narasimham, J.V. and Ananthan, G. (2019). Application of principal component regression analysis in agricultural studies. Internat. Res. J. Agric. Eco. \& Stat., 10 (1) : 5964, DOI : 10.15740/HAS/IRJAES/10.1/59-64. Copyright@ 2019: Hind Agri-Horticultural Society. 